\title{
Hypoxic conditioning as a new therapeutic modality
}

\author{
Samuel Verges ${ }^{1,2 *}$, Samarmar Chacaroun ${ }^{1,2}$, Diane Godin-Ribuot ${ }^{1,2}$ and \\ Sébastien Baillieul ${ }^{1,2}$
}

${ }^{1}$ Laboratoire HP2, Université Grenoble Alpes, Grenoble, France, ${ }^{2}$ U1042, INSERM, Grenoble, France

Preconditioning refers to a procedure by which a single noxious stimulus below the threshold of damage is applied to the tissue in order to increase resistance to the same or even different noxious stimuli given above the threshold of damage. Hypoxic preconditioning relies on complex and active defenses that organisms have developed to counter the adverse consequences of oxygen deprivation. The protection it confers against ischemic attack for instance as well as the underlying biological mechanisms have been extensively investigated in animal models. Based on these data, hypoxic conditioning (consisting in recurrent exposure to hypoxia) has been suggested a potential

OPEN ACCESS

Edited by:

Michele Samaja

University of Milan, Italy

Reviewed by:

Tetiana Viktor Serebrovska,

Bogomoletz Institute of Physiology,

Ukraine

Stephana Carelli,

University of Milan, Italy

*Correspondence:

Samuel Verges,

Laboratoire HP2 (U1042 INSERM),

Université Grenoble Alpes, UF

Recherche sur l'Exercice, Hôpital

Sud, Avenue Kimberley, Echirolles 38

434, France

sverges@chu-grenoble.fr

Specialty section:

This article was submitted to Pediatric

Cardiology, a section of the journal

Frontiers in Pediatrics

Received: 31 March 2015

Accepted: 03 June 2015

Published: 22 June 2015

Citation:

Verges S, Chacaroun $S$,

Godin-Ribuot D and Baillieul S (2015)

Hypoxic conditioning as a new

therapeutic modality.

Front. Pediatr. 3:58.

doi: 10.3389/fped.2015.00058 non-pharmacological therapeutic intervention to enhance some physiological functions in individuals in whom acute or chronic pathological events are anticipated or existing. In addition to healthy subjects, some benefits have been reported in patients with cardiovascular and pulmonary diseases as well as in overweight and obese individuals. Hypoxic conditioning consisting in sessions of intermittent exposure to moderate hypoxia repeated over several weeks may induce hematological, vascular, metabolic, and neurological effects. This review addresses the existing evidence regarding the use of hypoxic conditioning as a potential therapeutic modality, and emphasizes on many remaining issues to clarify and future researches to be performed in the field.

Keywords: intermittent hypoxia, conditioning, therapeutics, dose, humans, murines

\section{Introduction}

Intermittent hypoxia $(\mathrm{IH})$ is well known in clinical physiopathology as a central characteristic of obstructive sleep apnea syndrome (OSAS). Chronic cyclical (30-90 s cycles) severe hypoxia is recognized as a major mechanism underlying the adverse systemic consequences of OSAS. Desaturation-reoxygenation sequences lead to oxidative stress and the production of reactive oxygen species (ROS) (1). Increased ROS levels lead to increased expression of adhesion molecules (2), activation of leukocytes (3), and production of systemic inflammation (4). Oxidative stress, systemic inflammation, and sympathetic activation underlie marked cardiovascular and metabolic morbidities in OSAS. There are now convincing data regarding the association between hypertension, arrhythmias, stroke, coronary heart disease, increased cardiovascular mortality, metabolic dysregulation, and OSAS (5). Nocturnal exposure to IH in healthy subjects has been shown to increase daytime arterial blood pressure and sympathetic activity $(6,7)$. OSAS should therefore be considered as a systemic disease with IH leading to deleterious consequences throughout the organism.

Several arguments suggest, however, that hypoxic exposure may also lead to some positive adaptations of the human body, able to protect him from several pathological conditions. Athletes have been using hypoxic training as a training strategy for decades, with increasingly complex methods 
and technology aimed at improving sport performances (8). Interestingly, some epidemiologic data suggest that living at moderate altitude may be associated with lower prevalence of obesity (9-11). Voss et al. (11), for instance, found in a USA-wide representative sample of $>400,000$ subjects that after controlling for urbanization, temperature category, and behavioral and demographic factors, male and female Americans living $<500 \mathrm{~m}$ above sea level had 5.1 [95\% confidence interval (CI): 2.7-9.5] and 3.9 (95\% CI: 1.6-9.3) times the odds of obesity, respectively, compared to their counterparts living $>3000 \mathrm{~m}$. Although $\mathrm{IH}$ is essentially considered as a deleterious factor in OSAS, some results suggest that moderate OSAS may be associated with some protection against ischemic-reperfusion events $(12,13)$. IH may in this case enhance the number and function of endothelial progenitor cells, promoting angiogenesis and coronary collateral vessels for instance (14). The potential protective effect of $\mathrm{IH}$ exposure also arose from clinical studies, suggesting that patients who had strokes preceded by transient ischemic attacks (implying some hypoxic stress) in the same vascular territory often had less severe deficits at the onset of their stroke and more favorable outcomes $(15,16)$.

A number of animal studies have described over the past decades the effect of ischemic and hypoxic preconditioning, demonstrating that some pattern and severity of hypoxic exposure can provide protective effects against various deleterious stimuli. While these experimental studies focusing on preconditioning mostly looked at the effect of acute hypoxic conditioning (i.e., a single session of hypoxic exposure) to induce protection over a limited period of time, they opened perspectives regarding the induction of a more prolonged state of protection based on recurrent hypoxic exposure, i.e., hypoxic conditioning (or intermittent hypoxic training). After summarizing the principles of hypoxic (pre)-conditioning, this review will present the available evidence regarding the use of hypoxic conditioning for several pathological conditions as well as highlight the remaining questions and perspectives for future research.

\section{Principle of Hypoxic (Pre)-Conditioning}

Preconditioning is a procedure by which a potentially deleterious stimulus is applied near to but below the threshold of damage to the organism. Shortly after this preconditioning procedure or after some time delay, tissues and organs can develop resistance or tolerance to the same or similar noxious stimuli, therefore preventing or reducing the damage it may induce. The preconditioning phenomenon relies on the basic principle that organisms have developed complex and active defenses to counter adverse conditions such as starvation and oxygen deprivation. Many stimuli, such as ischemia, hypoxia, hypothermia, and pharmacological agents can induce a preconditioning response and modify the responses of the organism to subsequent stress conditions. To identify endogenous mechanisms of protection and repair, and to potentially use these mechanisms therapeutically, preconditioning strategies have been tested over the past decades.

In 1986, Murry et al. (17) first described the principle of ischemic preconditioning. Four cycles of 5-min ischemia followed by short episodes of reperfusion in dogs resulted in a remarkable reduction of infarct size following a subsequently induced myocardial ischemia-reperfusion (I/R) injury. A few years later, Shizukuda et al. (18) were able to demonstrate similar protective effects of hypoxia pre-treatment and ischemic preconditioning and introduced the term hypoxic preconditioning. Both the perfusion of dog hearts with severely hypoxic blood and a short preinsult period of ischemia of $5 \mathrm{~min}$ followed by $10 \mathrm{~min}$ of reperfusion subsequently resulted in a comparable reduction of the size of an infarct induced by $60 \mathrm{~min}$ of coronary artery occlusion (18).

Most of the studies demonstrating $\mathrm{IH}$-induced preconditioning effects in the heart and brain are derived from animal models mimicking OSAS. In a series of studies from our laboratory (1921), rats were subjected to various paradigms (i.e., pattern and severity of exposure) of acute hypoxia. Compared to normoxia, intermittent moderately severe hypoxia (inspiratory oxygen fraction, $\mathrm{FiO}_{2}=10 \%$ ) applied for $4 \mathrm{~h}$ improved the tolerance of the myocardium to ischemia and induced delayed preconditioning by reducing infarct size in isolated rat hearts. Conversely, constant moderately severe hypoxia for $4 \mathrm{~h}$ had no protective effect while applying a more severe $\mathrm{IH}\left(\mathrm{FiO}_{2}=5 \%\right)$ enhanced infarct size, clearly demonstrating that the effect of $\mathrm{IH}$ on infarct size was dependent on the pattern (intermittent versus continuous) and severity (10 versus $5 \% \mathrm{FiO}_{2}$ ) of hypoxic exposure (20) (Figure 1). In addition to myocardial protection, similar protective effects of hypoxic preconditioning were also described in the brain, with the discoveries that pre-exposure to hypoxia can prolong anoxic survival by preserving brain metabolism (22), that brain can adapt to anoxia by hypoxic pre-exposure (23), and finally with the description of ischemic preconditioning against ischemic neuronal damage (24). It should be emphasized that most IH exposure used to trigger hypoxic preconditioning induces hypocapnic hypoxemia (because of the hypoxia-induced hyperventilation), while OSAS

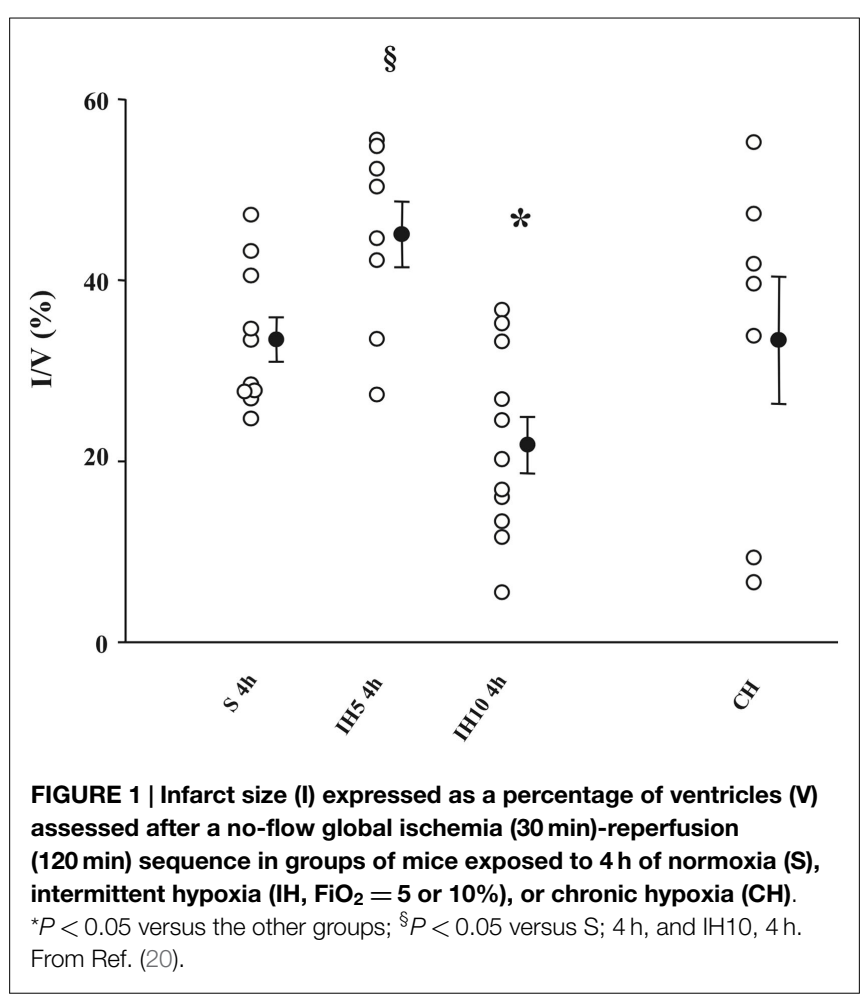


induces hypercapnic hypoxemia. Hence, the differences between the deleterious consequences of OSAS described earlier and the protective effects of hypoxic preconditioning might result not only from the severity of the IH stress but also from the differences in $\mathrm{CO}_{2}$ levels between both conditions.

Most of the studies mentioned above describe a preconditioning phenomenon consisting in acute ischemic or hypoxic exposure (i.e., a single exposure to hypoxia), leading to protection against subsequent ischemic insult for some hours or days only. However, several experimental studies suggest that conditioning strategies using repetitive exposure (several hypoxic exposures over days or weeks) to appropriate doses of hypoxia may induce a prolonged and sustained state of protection.

Hence, as early as 1960, the reported lower incidence of myocardial infarction in people living at high altitude (25) led to animal models describing protective effects of repetitive exposure to IH on the myocardium, more than 10 years (26) before the breakthrough study of Murry et al. on acute ischemic preconditioning (17). The chronic intermittent hypobaric hypoxia model was first designed to reproduce the beneficial effects of adaptation to high altitude. It was characterized by daily exposure to a sustained $(4-8 \mathrm{~h})$ period of hypobaric $(5000-7000 \mathrm{~m})$ hypoxia followed by a return to normoxic conditions. Intermittence was provided by repetition of this stimulus over several days. Thus, rats exposed to simulated high altitude $(5000 \mathrm{~m}, 8 \mathrm{~h} /$ day, 5 days/week, 24-32 days) have reduced I/R-induced myocardial necrosis (27), ventricular arrhythmia (28-30), and apoptosis (31). Overall, chronic intermittent hypobaric hypoxia exposure has consistently been shown to improve cardiac ischemic tolerance, with less adverse effects than chronic continuous hypoxia $(32,33)$. Most importantly, the myocardial infarct size-limiting effect of chronic intermittent hypobaric hypoxia appears to have a much longer time-span than that obtained with acute preconditioning protocols (34).

Recent studies have been investigating the protective effects of chronic repeated exposure to normobaric hypoxia. Hence, Stowe et al. (35) showed in mice that hypoxic conditioning by repeated hypoxia sequences ( 2 or $4 \mathrm{~h}, \mathrm{FiO}_{2}=8$ or $11 \%$ ) for 2 weeks protects against transient focal stroke for the following 8 weeks, together with reduced post-ischemic inflammation. A series of repetitive hypoxic conditioning stimuli $\left(2 \mathrm{~h}, \mathrm{FiO}_{2}=8\right.$ or $\left.11 \%\right)$ for 12 days can induce neuroprotection in the retina that lasts up to 4 weeks (36). Repetitive conditioning stimuli may therefore be an attractive option to provide prolonged protection.

Other results also suggest that intermittent hypoxic exposure may improve regeneration following an organ insult. Hence, conditioning strategies applied after focal ischemia and reperfusion (i.e., post-conditioning) have been proposed as a protective approach to lessen injury and improve recovery. In dogs, following lethal ischemia of the left anterior descending artery, it has been shown that three cycles of $30 \mathrm{~s}$ reperfusion and $30 \mathrm{~s}$ occlusion at the start of reperfusion reduced myocardial infarct size by $44 \%$ (37). Recovery may not only be enhanced by intervention in the minutes following acute ischemia but also by interventions applied over the days following the insult. For instance, in rats after ischemic brain injury IH exposure for 7 days with moderately reduced inspiratory oxygen fraction $\left(\mathrm{FiO}_{2}=12 \%, 4 \mathrm{~h}\right.$ per day) has been shown to enhance neurogenesis and to preserve spatial learning and memory (38). Hence, while acute preconditioning to protect against a subsequent ischemic insult occurring during the following hours has been originally described and most deeply investigated, alternative conditioning strategies include repetitive conditioning stimuli in order to provide prolonged state of protection or regeneration. Such strategies may not only apply to protection or recovery associated with ischemic insults but also to other cardiovascular, metabolic, and neurological disorders (see below). Hypoxic exposure can be used to trigger conditioning phenomenon when applied at rest but also when combined with exercise (exercise training in hypoxia, see below) or with hyperoxic exposure [intermittent hypoxic-hyperoxic training, e.g., Ref. $(39,40)]$.

\section{Potential Mechanisms Triggered by Hypoxic Conditioning}

As mentioned above, the time-course of protection afforded by hypoxic conditioning can be extended by increasing the duration of the conditioning protocol (34). This could be due to the recruitment of additional protective mechanisms in response to repetitive exposure. In this section, we review the various mechanisms involved in the beneficial effects of both acute and longterm $\mathrm{IH}$ exposure in order to propose a potential explanation for this phenomenon.

Whether acute or repeated, hypoxic conditioning appears to be accompanied by substantial changes in gene expression. A crucial mediator of this genomic response is the hypoxia-inducible factor 1 (HIF-1) transcription factor, a key regulator of cellular oxygen homeostasis. HIF-1 is a complex protein composed of two subunits, the cytosolic HIF- $1 \alpha\left(\mathrm{O}_{2}\right.$-sensitive) subunit and the nuclear HIF-1 $\beta$ subunit, which dimerize in the nucleus to form the functional HIF-1 transcription factor and activate gene transcription. In well-oxygenated cells, proline hydroxylation of the HIF$1 \alpha$ subunit by prolyl-hydroxylase enzymes (PHDs) leads to ubiquitination and proteasomal degradation. In sustained hypoxic conditions, HIF- $1 \alpha$ hydroxylation and subsequent degradation are reduced because of substrate $\left(\mathrm{O}_{2}\right)$ limitation, so that HIF- $1 \alpha$ translocates to the nucleus to bind HIF-1 $\beta$ and activate the transcription of various genes geared to maintain cellular homeostasis under reduced oxygen availability. Upon return to normoxic conditions, cytosolic levels of HIF- $1 \alpha$ rapidly decline and the effects of HIF-1 decrease (41).

The major role of HIF-1 and its target genes in ischemic/hypoxic conditioning is evidenced by the complete loss of ischemia-induced cardioprotection in mice with partial HIF-1 deficiency (42). Similarly, we have shown that prevention of HIF1 activation abolished the delayed cardio-protection provided by acute $\mathrm{IH}$ in the rat (21), and a recent study reported that HIF-1 inhibition prevented the acute IH-induced neuroprotection (43).

Nitric oxide (NO) is known to play a critical role in preconditioning and cytoprotection through its vasodilating effect as well as for its ability to modulate mitochondrial function (44). Others and we have shown that the inducible nitric oxide synthase (iNOS) gene, a HIF-1 target gene, is up-regulated along with HIF1 activation in response to acute exposure to $\mathrm{IH}(21,45)$ and 
that NO is involved in its delayed protective effects $(20,21,46)$. In addition to HIF-1, GATA-4, a transcription factor involved in the regulation of apoptosis, has been shown to activate the gene expression of the anti-apoptotic proteins, bcl-2 and bcl-x $(\mathrm{L})$, following acute IH exposure in mice (47). Finally, well-known mediators of classic ischemic preconditioning are also triggered by acute IH exposure. Hence, we have evidenced the role of ATPdependent potassium $\left(\mathrm{K}_{\mathrm{ATP}}\right)$ channels $(20)$ and of stress-activated kinases such as protein kinase C (PKC), p38 mitogen-activated protein kinase (MAPK), and extracellular signal-regulated kinase (ERK1/2) (19) in the cardio-protection induced by a 4-h exposure to moderately severe $(\mathrm{FiO} 2=10 \%) \mathrm{IH}$.

Although the effects of HIF-1 rapidly decline upon reoxygenation following sustained hypoxia, we have found that $\mathrm{IH}$ induces a strong and sustained whole-body activation of HIF-1 that persists after IH exposure. This can be explained by the oxidative stress produced by the repetition of oxygenation-desaturation sequences. Indeed, ROS are potent inductors of HIF-1 by increasing the expression of the HIF- $1 \alpha$ protein and by inhibiting its PHD-dependent degradation (41). Repeated IH exposure could thus result in activation of additional cytoprotective genes that are not or insufficiently expressed upon sustained hypoxia or short-term IH exposure.

Consequently, in addition to involving the iNOS gene (48) and the $\mathrm{K}_{\mathrm{ATP}}$ channels (49), chronic IH has also been shown to promote the expression of the erythropoietin (EPO) gene (50). EPO is well recognized as a potent protective agent against ischemic injury since its binding to EPO receptors activates numerous protective signaling pathways, such as Janus kinase 2 (JAK2)/signal transducer and activator of transcription 3 (STAT3) pathway, the phosphatidylinositol 3-kinase (PI3K)/protein kinase B (Akt) pathway, and the MAPK pathway, all known to confer cytoprotection, in particular cardioprotection (51), nephroprotection (52), and neuroprotection (53). A recent study confirms the pivotal role of the JAK2/STAT3 pathway in a cardioprotective chronic IH model. Activation of the pathway by a 4 -week exposure to chronic IH was directly linked to improvement of functional recovery upon reperfusion via maintenance of intracellular $\mathrm{Ca}^{2+}$ homeostasis and of mitochondrial function (54). The involvement of other EPOrelated signaling pathways, such as the PI3K/Akt pathway, has also been confirmed in the infarct size-sparing effects of chronic IH exposure $(55,56)$. Interestingly, we observed that (PI3K)/Akt pathway was not involved in the cardioprotection afforded by acute IH exposure (19). This is in agreement with the notion that long-term exposure can trigger additional protective mechanisms, particularly through EPO production. In accordance, EPO has been shown to play a pivotal role in the cerebral infarct size reduction provided by chronic IH post-conditioning in mice (57).

Among the other tissue protective genes upregulated by HIF-1 upon long-term hypoxic exposure are genes encoding angiogenic growth factors and cytokines, such as vascular endothelial growth factor (VEGF), angiopoietins, and platelet-derived growth factors (41). In agreement, rats exposed to chronic IH display a 1.5fold increase in left ventricular capillary, a higher pre-ischemic coronary flow of isolated hearts and an improved recovery after I/R (58). We also found an increased myocardial capillary density and VEGF expression in rats exposed to 35 days of normobaric
IH (59). This increase in angiogenesis might not only contribute to the cytoprotection conferred by repeated hypoxic conditioning but could also explain why the protection lasts longer than that obtained with acute conditioning protocols.

Finally, other important mediators of the cytoprotective effects of chronic IH are heat stress proteins (HSP), in particular the HSP70 family, also regulated by HIF-1 (60). HSP70 are thought to act as molecular chaperones to repair or remove proteins denatured by stresses such as I/R, leading to protection and/or restoration of cell function (61). Thus, hypoxic preconditioning has been shown to reinforce HIF-1-dependent HSP70 signaling with beneficial effects on ischemic renal apoptosis and autophagy (60) as well as occurrence of I/R-induced ventricular arrhythmias (62).

\section{Hypoxic Conditioning in Healthy Subjects}

Intermittent hypoxia training is recognized by the sports medicine community as a potentially useful strategy to enhance exercise performance in athletes (8). Living or training under hypoxic conditions may improve exercise performance probably by promoting hematological and muscle adaptations and without eliciting the detrimental effects of chronic hypoxic exposure. Several studies focusing on these types of hypoxic training programs reported promising results especially in terms of performance gain, but some debates remain regarding the usefulness of IH training in athletes (63). Beyond the enhancement of physical performances $(8,64)$, and on the basis of some established protective preclinical effects of $\mathrm{IH}$, hypoxic conditioning in healthy subjects has been evaluated as a potential useful intervention to improve some physiological functions and risk factors for acute and chronic diseases.

\section{Hematology}

As demonstrated following environmental exposure to sustained hypobaric hypoxia (e.g., altitude) (65), moderate IH exposure can also trigger hematological changes. Nine days of hypobaric IH exposure (simulated altitude ranging from 4000 to $5500 \mathrm{~m}, 3-5 \mathrm{~h} /$ day) induced a significant increase in hematocrit, red blood cell count, reticulocytes, and hemoglobin concentration (66). Hellemans (67) showed that normobaric IH sessions ( 5 min $\mathrm{FiO}_{2}=9-10 \%$ alternating with $5 \mathrm{~min}$ of normoxia, $60 \mathrm{~min}$ per day, twice a day, for 18 days) in 10 elite endurance athletes triggered significant increases in reticulocyte count $(30 \%)$, hemoglobin $(4 \%)$, and hematocrit $(5 \%)$. Hence, while continuous and prolonged exposure to hypoxia triggers significant and sustained hematological effects, IH protocols with substantially lower total hypoxic doses seem to be sufficient to enhance erythropoiesis (68).

\section{Ventilation}

Beyond the well-known increase in hypoxic ventilatory response associated with prolonged hypoxic exposure, IH may elicit specific forms of respiratory plasticity. Briefly, respiratory plasticity is defined as a persistent change in the neural pathways and synapses (morphology and/or function) of the nervous system involved in generating respiratory activity, in response to prior experience 
(69). In the context of $\mathrm{IH}$, respiratory plasticity is referred to longterm facilitation (LTF) (70). Ten brief bouts ( $3 \mathrm{~min}$ ) of isocapnic hypoxia $\left(\mathrm{FiO}_{2}=8 \%\right)$, interspersed with $5 \mathrm{~min}$ of normoxia applied during non-rapid eye movement sleep in healthy subjects (71) and snoring individuals (72) reduced upper airway resistance, suggesting LTF of upper airway dilatators and more particularly hypoglossal muscle LTF (73). Hence, based on these results suggesting that IH exposure may trigger respiratory plasticity in physiological conditions, translating the use of hypoxic conditioning to pathological conditions seems to be relevant and will be discussed later in this review.

\section{Cardiovascular System}

In contrast to the harmful effects of chronic IH upon the cardiovascular system observed in severe OSAS, moderate IH may induce some positive cardiovascular adaptations. Shatilo et al. (74) submitted two groups of healthy 60- to 74-year-old men (14 physically active, 21 sedentary) to normobaric $\mathrm{IH}$ (cycles of 5 min hypoxia, $\mathrm{FiO}_{2}=12 \%$, followed by 5 min normoxia, repeated four times a day during 10 days). In sedentary subjects only, $\mathrm{IH}$ induced a decrease in blood pressure of $7.9 \pm 3.1 \mathrm{mmHg}$ and an increase in submaximal exercise capacity (workload at anaerobic threshold $+12.7 \%$ ), highlighting the positive cardiovascular effects of hypoxic conditioning in healthy older inactive men. Supporting these results, and by combining hypoxic exposure and exercise, Bailey et al. (75) exposed, in a randomized controlled and double blind manner, 34 physically active subjects to either a normoxic $\left(n=14, \mathrm{FiO}_{2} \approx 20.9 \%\right)$ or a hypoxic $(n=18$, $\mathrm{FiO}_{2} \approx 16 \%$ ) training (cycling three times per week for $20-30 \mathrm{~min}$ at $70-85 \%$ of maximum heart rate previously determined either in normoxia or hypoxia, during 4 weeks). Hypoxic exercise training only significantly decreased maximal exercise systolic blood pressure by $10 \pm 9 \mathrm{mmHg}$ and increased maximal oxygen uptake by $0.47 \pm 0.77 \mathrm{~L} / \mathrm{min}$.

Increased arterial stiffness is known to be associated with an increase in the risk of occurrence of cardiovascular events (76). The beneficial aspects of combining hypoxic exposure and exercise training upon arterial stiffness have been studied in women. Sixteen postmenopausal women were randomly allocated either to a hypoxic exercise group $(n=8$, hypobaric hypoxic chamber, $2000 \mathrm{~m}, 2 \mathrm{~h}$ exposure per session, 4 days per week, during 8 weeks) or a normoxic exercise group $(n=8,2 \mathrm{~h}$ exposure per session, 4 days per week, during 8 weeks). Exercise (aquatic exercises) was performed in both groups under normoxic or hypoxic conditions at an intensity of $\approx 50 \%$ peak oxygen uptake for $30 \mathrm{~min}$. Mild hypoxic exposure combined with exercise training significantly reduced arterial stiffness in postmenopausal women, while exercise training performed at the same relative intensity under normoxic conditions did not induce any change (77). These results corroborate the work of Vedam et al. (78) showing an NO-mediated reduction in arterial stiffness among healthy adults men exposed to a single hypoxic session ( $n=12$, arterial oxyhemoglobin saturation $\approx 80 \%$ during $20 \mathrm{~min}$ ) compared to subjects evaluated under room-air conditions.

Taken together, these results confirm the potential positive effects of hypoxic conditioning on the cardiovascular function in healthy subjects, including older individuals and females.

\section{Metabolic Status}

Preclinical data indicate a potential beneficial impact of moderate IH exposure on blood glucose and cholesterol levels, mitochondrial enzyme activity, glycolysis, and fatty-acid oxidation (7981). In healthy humans also, some data suggest that $\mathrm{IH}$ either at rest or combined with exercise training can improve metabolic status. In a single blind, randomized controlled trial, Haufe at al. (82) have shown in 20 healthy lean subjects that performing endurance training in hypoxia (60 min of treadmill running, three times a week during 4 weeks, $\mathrm{FiO}_{2}=15 \%$ ) compared to normoxia $\left(\mathrm{FiO}_{2}=21 \%\right)$ at the same relative intensity elicit greater reduction in body fat mass as well as in circulating triglyceride and fasting insulin levels. Interestingly, these effects were observed despite of a smaller absolute workload during hypoxic exercise training.

Intermittent hypoxia exposure can also significantly modify appetite regulation. Bailey et al. (83) reported that a $3 \mathrm{~h}$ exposure to normobaric hypoxia while performing a $50 \mathrm{~min}$ exercise in 12 healthy males caused a suppression in appetite and a reduction in plasma levels of acylated ghrelin concentrations, the hungerstimulating hormone.

\section{Hypoxic Conditioning for Patients}

Based on preclinical data as well as on studies in healthy subjects showing potential positive effects of $\mathrm{IH}$ exposure, pilot investigations have been conducted in various pathological conditions to assess the potential clinical application of hypoxic conditioning (Table 1).

\section{Cardiovascular Diseases Hypertension and Vascular Function}

Murine models have demonstrated the antihypertensive effect of hypoxic conditioning as observed in spontaneously hypertensive rats. This effect seems to be mediated, at least in part, by NO metabolism, which may underlie hypoxia-induced prevention of endothelial dysfunction, a well-known major risk for hypertension (100-102). IH has been proposed as a mean to treat hypertension in humans. Serebrovskaya et al. (102) highlight in their review encouraging results reported in the Russian literature with noteworthy improvements in blood pressure (e.g., a decrease of $10-30 \mathrm{mmHg}$ in systolic and $10-15 \mathrm{mmHg}$ in diastolic blood pressure) following exposure to only a few episodes of moderate hypoxia $\left(\mathrm{FiO}_{2}=10-14 \%\right)$ for a short duration (15 min to $4 \mathrm{~h}$ per session) for 10-30 days. In a more recent study, Lyamina et al. (85) exposed 37 young non-overweight men with stage 1 hypertension to 20 sessions of 4 to 10 cycles of 3-min hypoxia $\left(\mathrm{FiO}_{2}=10 \%\right)$ and 3-min room air breathing. A significant decrease in blood pressure was observed following the intervention with values in patients not different anymore from the normotensive control group. Moreover, the reduction in blood pressure persisted for up to 3 months in 28 initially hypertensive patients. Thus, considering the good tolerance profile and apparently harmless aspect of moderate IH conditioning protocols, it could be considered as an interesting and promising adjunct therapeutic strategy to reduce systemic blood pressure. 
TABLE 1 | Characteristics of hypoxic conditioning interventions in patients.

\begin{tabular}{|c|c|c|c|c|c|}
\hline \multirow[t]{2}{*}{ Author } & \multirow[t]{2}{*}{ Subjects } & \multicolumn{4}{|c|}{ Conditioning stimulus } \\
\hline & & Duration & Hypoxic intervention & Control intervention & Exercise/rest \\
\hline \multicolumn{6}{|c|}{ CARDIOVASCULAR DISEASES } \\
\hline $\begin{array}{l}\text { Burtscher } \\
\text { et al. (84) }\end{array}$ & $\begin{array}{l}16 \text { elderly men } \\
\text { (50-70years old, eight } \\
\text { with prior myocardial } \\
\text { infarction, and eight } \\
\text { without) }\end{array}$ & $\begin{array}{l}3 \text { weeks, } 5 \text { sessions a } \\
\text { week ( } 15 \text { sessions) }\end{array}$ & $\begin{array}{l}\text { Three to five times } 3-5 \mathrm{~min} \\
\text { hypoxia } \\
(\mathrm{FiO}=10-14 \%)-3 \mathrm{~min} \\
\text { normoxia }\end{array}$ & $\begin{array}{l}\text { Normoxia ( } 3 \text { weeks of } \\
\text { exposure, five sessions } \\
\text { a week) }\end{array}$ & Rest \\
\hline $\begin{array}{l}\text { Lyamina } \\
\text { et al. ( } 85)\end{array}$ & $\begin{array}{l}37 \text { young non-overweight } \\
\text { men with stage } 1 \\
\text { hypertension ( } 32 \text { years old) }\end{array}$ & $\begin{array}{l}20 \text { consecutive days, } \\
\text { one session a day }\end{array}$ & $\begin{array}{l}\text { Four to } 10 \text { times } 3 \mathrm{~min} \\
\text { hypoxia }\left(\mathrm{FiO}_{2}=10 \%\right)-3 \mathrm{~min} \\
\text { normoxia }\end{array}$ & $\begin{array}{l}20 \text { normotensive } \\
\text { participants ( } 35 \text { years } \\
\text { old), no exposure }\end{array}$ & Rest \\
\hline \multicolumn{6}{|c|}{ NEUROLOGICAL DISEASES } \\
\hline $\begin{array}{l}\text { Trumbower } \\
\text { et al. (86) }\end{array}$ & $\begin{array}{l}13 \text { subjects with } \\
\text { incomplete SCI, ASIA } \\
\text { Score C or D }\end{array}$ & One single session & $\begin{array}{l}15 \text { times } 60 \text { or } 90 \text { s hypoxia } \\
\left(\mathrm{FiO}_{2}=9 \%\right)-60 \text { s normoxia }\end{array}$ & Normoxia & Rest \\
\hline $\begin{array}{l}\text { Schega } \\
\text { et al. ( } 87)\end{array}$ & $\begin{array}{l}34 \text { healthy subjects } \\
\text { (60-70years), cognitively } \\
\text { preserved }\end{array}$ & $\begin{array}{l}6 \text { weeks, } 3 \text { sessions a } \\
\text { week ( } 18 \text { sessions) }\end{array}$ & $\begin{array}{l}1 \mathrm{~h} / \text { session, } 10 \text { min hypoxia } \\
\left(\mathrm{FiO}_{2} \text { adjusted to reach a }\right. \\
\mathrm{SpO}_{2}=90 \% \text { the first } \\
2 \text { weeks, } 85 \% \text { the third week } \\
\text { and } 80 \% \text { the last three } \\
\text { weeks })-5 \text { min normoxia }\end{array}$ & Normoxia & $\begin{array}{l}30 \text { min } \\
\text { strength-endurance } \\
\text { training after each } \\
\text { normoxia/hypoxia session }\end{array}$ \\
\hline $\begin{array}{l}\text { Hayes } \\
\text { et al. (88) }\end{array}$ & $\begin{array}{l}19 \text { subjects with } \\
\text { incomplete chronic SCI, } \\
\text { ASIA Score C or D }\end{array}$ & $\begin{array}{l}5 \text { consecutive days, one } \\
\text { session a day }\end{array}$ & $\begin{array}{l}15 \text { times } 90 \text { s hypoxia } \\
\left(\mathrm{FiO}_{2}=9 \%\right)-60 \text { s normoxia }\end{array}$ & Normoxia & $\begin{array}{l}\text { Conditioning at rest or } \\
\text { combined with a } 30-\text { min } \\
\text { over-ground walking } \\
\text { training performed } 1 \mathrm{~h} \text { later }\end{array}$ \\
\hline $\begin{array}{l}\text { Tester et al. } \\
\text { (89) }\end{array}$ & $\begin{array}{l}\text { Eight individuals with } \\
\text { cervical or thoracic } \\
\text { incomplete SCI, ASIA } \\
\text { Score ranging from A to D }\end{array}$ & $\begin{array}{l}10 \text { consecutive days, } \\
\text { one session a day }\end{array}$ & $\begin{array}{l}\text { Eight times } 2 \text { min hypoxia } \\
\left(\mathrm{FiO}_{2}=8 \%\right)-2 \mathrm{~min} \\
\text { normoxia, controlled end-tidal } \\
\mathrm{CO} 2 \text { level ( } 2 \mathrm{mmHg} \text { above } \\
\text { resting values) }\end{array}$ & $\begin{array}{l}\text { Normoxia in a subset } \\
\text { of } n=4 \text { subjects } 1 \text { day } \\
\text { before and } 10 \text { days } \\
\text { after conditioning }\end{array}$ & Rest \\
\hline \multicolumn{6}{|c|}{ VENTILATION/RESPIRATORY DISEASES } \\
\hline $\begin{array}{l}\text { Aboubakr } \\
\text { et al. (90) }\end{array}$ & 11 severe OSAS patients & $\begin{array}{l}\text { One night session during } \\
\text { non-rapid-eye } \\
\text { movement sleep before } \\
\text { and after } 4 \text { weeks of } \\
\text { CPAP treatment }\end{array}$ & $\begin{array}{l}10 \text { times } 3 \text { min hypoxia } \\
\left(\mathrm{FiO}_{2}=8 \%\right)-5 \mathrm{~min} \\
\text { normoxia, isocapnia }\end{array}$ & $\begin{array}{l}\text { One-night normoxia, } \\
\text { subset of } n=7\end{array}$ & Rest \\
\hline $\begin{array}{l}\text { Rowley } \\
\text { et al. (91) }\end{array}$ & 13 OSAS patients & $\begin{array}{l}\text { One night session during } \\
\text { non-rapid-eye } \\
\text { movement sleep }\end{array}$ & $\begin{array}{l}10 \text { times } 3 \text { min hypoxia } \\
\left(\mathrm{FiO}_{2}=8 \%\right)-5 \text { min } \\
\text { normoxia, isocapnia }\end{array}$ & $\begin{array}{l}\text { One-night normoxia, } \\
\text { subset of } n=8\end{array}$ & Rest \\
\hline $\begin{array}{l}\text { Burtscher } \\
\text { et al. (92) }\end{array}$ & $\begin{array}{l}18 \text { eucapnic normoxic } \\
\text { mild COPD patients }\end{array}$ & $\begin{array}{l}3 \text { weeks, } 5 \text { sessions a } \\
\text { week ( } 15 \text { sessions) }\end{array}$ & $\begin{array}{l}3 \text { to } 5 \text { times } 3-5 \text { min hypoxia } \\
\left(\mathrm{FiO}_{2}=12-15 \%\right)-3 \mathrm{~min} \\
\text { normoxia }\end{array}$ & Normoxia & Rest \\
\hline $\begin{array}{l}\text { Haider } \\
\text { et al. (93) }\end{array}$ & $\begin{array}{l}18 \text { eucapnic normoxic } \\
\text { mild COPD patients }\end{array}$ & $\begin{array}{l}3 \text { weeks, } 5 \text { sessions a } \\
\text { week ( } 15 \text { sessions) }\end{array}$ & $\begin{array}{l}\text { Three to five times } 3-5 \mathrm{~min} \\
\text { hypoxia } \\
\left(\mathrm{FiO}_{2}=12-15 \%\right)-3 \mathrm{~min} \\
\text { normoxia }\end{array}$ & $\begin{array}{l}\text { Normoxia } \\
\text { Age-matched healthy } \\
\text { controls, } n=14\end{array}$ & Rest \\
\hline \multicolumn{6}{|c|}{ METABOLIC DISEASES } \\
\hline $\begin{array}{l}\text { Netzer } \\
\text { et al. (94) }\end{array}$ & 20 obese subjects & $\begin{array}{l}8 \text { weeks, } 3 \text { sessions a } \\
\text { week ( } 24 \text { sessions) }\end{array}$ & 90 min hypoxia $\left(\mathrm{FiO}_{2}=15 \%\right)$ & $\begin{array}{l}\text { Normoxia, } \\
\text { sham-exposure }\end{array}$ & $\begin{array}{l}\text { Stepper, treadmill and } \\
\text { bicycle ergometer-training } \\
\text { combined with } \\
\text { conditioning, without any } \\
\text { dietary intervention }\end{array}$ \\
\hline $\begin{array}{l}\text { Wiesner } \\
\text { et al. (95) }\end{array}$ & $\begin{array}{l}45 \text { sedentary overweight } \\
\text { or obese subjects, } \\
\text { non-diabetic or } \\
\text { insulin-resistant }\end{array}$ & $\begin{array}{l}4 \text { weeks, } 3 \text { sessions a } \\
\text { week ( } 12 \text { sessions) }\end{array}$ & 60 min hypoxia $\left(\mathrm{FiO}_{2}=15 \%\right)$ & Normoxia & $\begin{array}{l}\text { Treadmill-training } \\
\text { combined with } \\
\text { conditioning }\end{array}$ \\
\hline $\begin{array}{l}\text { Mackenzie } \\
\text { et al. (96) }\end{array}$ & $\begin{array}{l}\text { Eight type } 2 \text { diabetic } \\
\text { patients }\end{array}$ & One single session & 60 min hypoxia $\left(\mathrm{FiO}_{2}=15 \%\right)$ & Normoxia & $\begin{array}{l}\text { Four conditions for all } \\
\text { patients: Rest: hypoxia } \\
\text { and normoxia; Cycling: } \\
\text { hypoxia and normoxia }\end{array}$ \\
\hline
\end{tabular}




\begin{tabular}{|c|c|c|c|c|c|}
\hline \multirow[t]{2}{*}{ Author } & \multirow[t]{2}{*}{ Subjects } & \multicolumn{4}{|c|}{ Conditioning stimulus } \\
\hline & & Duration & Hypoxic intervention & Control intervention & Exercise/rest \\
\hline $\begin{array}{l}\text { Mackenzie } \\
\text { et al. (97) }\end{array}$ & $\begin{array}{l}\text { Eight type } 2 \text { diabetic } \\
\text { patients }\end{array}$ & $\begin{array}{l}\text { One single } 60,40 \text { and } \\
20 \text {-min session, } \\
\text { combined with exercise }\end{array}$ & $\begin{array}{l}60,40 \text { and } 20 \text { min hypoxia } \\
\left(\mathrm{FiO}_{2}=15 \%\right)\end{array}$ & No control group & 60,40 , and 20 min cycling \\
\hline $\begin{array}{l}\text { Workman } \\
\text { and Basset } \\
\text { et al. (98) }\end{array}$ & $\begin{array}{l}15 \text { sedentary overweight } \\
\text { males }\end{array}$ & $\begin{array}{l}\text { One session. A subset of } \\
n=6 \text { underwent } \\
\text { conditioning on } 6 \\
\text { consecutive days }\end{array}$ & $\begin{array}{l}\text { 3h hypoxia, targeted } \mathrm{SpO}_{2} \approx \\
80 \%\end{array}$ & 3h normoxia & Rest \\
\hline $\begin{array}{l}\text { Kong et al. } \\
\text { (99) }\end{array}$ & 18 young obese subjects & $\begin{array}{l}4 \text { weeks, } 3 \text { sessions a } \\
\text { week, cumulative } \\
\text { exposure of } 6 \mathrm{~h} / \text { week }\end{array}$ & $\begin{array}{l}2 \mathrm{~h} \text { hypoxia } \\
\left(\mathrm{FiO}_{2}=14.5-16.4 \%\right)\end{array}$ & $2 \mathrm{~h}$ normoxia & $\begin{array}{l}\text { Endurance and strength } \\
\text { training combined with a } \\
\text { low-calorie intake diet }\end{array}$ \\
\hline
\end{tabular}

ASIA, American Spinal Injury Association; COPD, chronic obstructive pulmonary disease; $\mathrm{FiO}_{2}$, fraction of inspired oxygen; $h$, hour(s); min, minute(s); Normoxia (FiO ${ }_{2}=21 \%$ ); OSAS, obstructive sleep apnea syndrome; s, second(s); $\mathrm{SCl}$, spinal cord injury; $\mathrm{SpO}_{2}$, peripheral capillary oxygen saturation.

\section{Acute Myocardial Infarction}

In addition to its potential effect on the vascular function and blood pressure, hypoxic conditioning strategies may be useful to improve heart function and prevent the early and delayed deleterious consequences of myocardial infarction. Forty days of hypobaric IH exposure before ligation of the left coronary artery in mice reduced myocardial infarct size and mortality rates (26). The same intervention applied after ligation was also shown to reduce the risk of arrhythmia occurrence (29). Normobaric IH protocols induce the same effects, with reduced cardiac arrhythmias during ischemia and decreased infarct size by $43 \%$ following ischemiareperfusion injury (103). However, in humans, since myocardial infarction is not a predictable event, similar hypoxic preconditioning strategies using $\mathrm{IH}$ are actually difficult to implement.

Besides hypoxic conditioning, ischemic conditioning, consisting in brief ischemic episodes, even remote (lower or upper limb intermittent ischemia), can enhance myocardial tolerance to subsequent ischemic or ischemia-reperfusion insults. Based on preclinical remote or perioperative ischemic conditioning studies (17, 104), clinical studies have been conducted to evaluate the effect of remote ischemic conditioning (RIC) in patients. In a randomized controlled study, 333 consecutive adult patients with a suspected first acute myocardial infarction were assigned to receive a primary percutaneous coronary intervention with (interventional group, unilateral intermittent upper-arm ischemia, four cycles of 5 min inflation up to $200 \mathrm{mmHg}$ and $5 \mathrm{~min}$ deflation of a standard upper-arm pressure cuff) or without (control group) prior RIC during transport to hospital. In addition to the favorable safety profile of RIC, a significant increase in myocardial salvage, an established prognostic factor of mortality (105), has been shown when RIC was applied (106). More recently, and using the same study design and RIC paradigm in patients presenting with a STsegment elevation myocardial infarction, the group treated with RIC prior to primary percutaneous coronary intervention showed reduced myocardial infarct size, increased myocardial salvage, and reduced myocardial edema (107).

\section{Chronic Coronary Artery Disease}

The beneficial role of $\mathrm{IH}$ in chronic coronary artery disease has also been considered (32). An augmented coronary collateral vessel development has been reported in OSAS patients (apneahypopnea index $>10$ events/h) (13) suggesting that some degree of IH may induce positive myocardial adaptations. In a prospective controlled study in 16 elderly men (50-70 years old, eight with prior myocardial infarction and eight without), subjects were assigned randomly and in a double-blind fashion to moderate IH [ 3 weeks, 15 passive exposure sessions, three to five episodes (3-5 min) of hypoxia $\left(\mathrm{FiO}_{2}=10-14 \%\right)$ per session with 3 -min normoxic interval] or normoxia (control group, 3 weeks of exposure). An increased peak-oxygen consumption following hypoxic conditioning was shown both in subjects with and without prior myocardial infarction compared to normoxic exposure (84). Furthermore, heart rate, systolic blood pressure, blood lactate concentration, and the rating of perceived exertion during submaximal exercise (cycling at $1 \mathrm{~W} / \mathrm{kg}$ ) were diminished in subjects exposed to IH. Hence, IH exposure may be considered in chronic coronary artery disease as a procedure to improve cardiovascular parameters.

\section{Heart Failure}

Preclinical studies in healthy lean mice (108) and in a mice model of heart failure (109) showed an improved cardiac function following 4 weeks of exposure to IH. In patients with heart failure, a syndrome resulting from several cardiac injuries, IH has not been clinically tested yet, but encouraging results regarding RIC are actually available. Kono et al. (110) reported increased coronary flow reserve both in subjects with heart failure $(n=10)$ and in healthy subjects $(n=10)$ following 1 week of upper-limb RIC ( 4 cycles of 5 min inflation and 5 min deflation of a blood pressure cuff).

While current preclinical and clinical results suggest that IH may be an innovative and non-pharmacological therapeutic option in cardiovascular diseases, additional clinical studies are required in patients with various cardiac conditions to confirm the potential of hypoxic conditioning as a therapeutic tool.

\section{Neurological Diseases Stroke}

The protective effects of hypoxic conditioning are not restricted to the heart and may also apply to the brain. Remarkable clinical 
and preclinical data support the ability of hypoxic/ischemic conditioning to enhance brain tolerance to ischemia. In humans, retrospective studies $(15,16)$ or prospective studies $(111)$ and clinical evidence $(112,113)$ have reported lower severity and better functional outcome following stroke in patients who have previously experienced spontaneous transient ischemic attacks. Despite some discrepancies (114-116), these findings suggest an endogenous ischemic neuroprotective preconditioning triggered by transient ischemic attacks. As for myocardial infarction, the unpredictable nature of stroke actually restrains the clinical applicability of hypoxic/ischemic preconditioning. Post-conditioning might be a useful alternative paradigm. It refers to the application of the conditioning stimulus after the occurrence of the harmful event in order to treat or prevent its consequences. In rodents, 7 days after transient mild cerebral artery occlusion, exposure to moderate $\mathrm{IH}$ for 7 days induced hippocampal neurogenesis, synaptogenesis, increased brain-derived neurotrophic factor expression, and significantly improved functional outcomes regarding spatial learning and memory (117). RIC following acute ischemic stroke has also been studied in preclinical (118) and clinical (119) conditions alone or as an adjunct therapy to conventional fibrinolysis with encouraging results in both cases. Since hypoxic/ischemic conditioning seems to be harmless and relatively easy to implement at bedside, it may represent a promising adjunct therapy in stroke patients.

\section{Spinal Cord Injury}

Trumbower et al. (86) exposed, in a randomized controlled single blind crossover trial, 13 incomplete spinal cord injury (SCI) subjects to 15 repeated bouts of $\mathrm{IH}\left(60\right.$ or $90 \mathrm{~s}, \mathrm{FiO}_{2}=9 \%$ ), separated by $60 \mathrm{~s}$ of normoxic exposure $\left(\mathrm{FiO}_{2}=21 \%\right)$. Hypoxic sessions were compared to sessions in which subjects received sham exposure (i.e., room air). Changes in maximum isometric ankle plantar flexor torque generation were significantly increased by $82 \pm 33 \%$ immediately after $\mathrm{IH}$ exposure and were maintained above baseline for more than $90 \mathrm{~min}$. Increased ankle plantar flexor electromyogram activity was correlated with increased torque $\left(r^{2}=0.5, P<0.001\right)$. There was no change from baseline following sham experiments. Hayes et al. (88), in a randomized, double blind, placebo-controlled, crossover study, exposed 19 participants with chronic incomplete SCI to 15 repetitions of $90 \mathrm{~s}$ hypoxic exposure $\left(\mathrm{FiO}_{2}=9 \%\right)$ interspersed by $60 \mathrm{~s}$ normoxia or to normoxic exposure $\left(\mathrm{FiO}_{2}=21 \%\right.$, placebo $)$ on five consecutive days, alone or combined with $30 \mathrm{~min}$ of over-ground walking $1 \mathrm{~h}$ later. In this study, $\mathrm{IH}$ improved both walking speed and endurance, and the impact of hypoxia exposure was enhanced when combined with walking (88). Beyond motor function enhancement, IH could also promote recovery of respiratory motor function: a recent case study has outlined an improvement in airflow in response to resistive loads applied in a 55-yearold woman with chronic SCI following acute exposure to $\mathrm{IH}$ (120). Furthermore, in a controlled trial, eight individuals with either cervical $(n=6)$ or thoracic $(n=2)$ incomplete SCI were exposed to $\mathrm{IH}$ [eight 2 min hypoxic bouts $\left(\mathrm{FiO}_{2}=8 \%\right)$ interspersed with a $2 \mathrm{~min}$ recovery period (room air, $\mathrm{FiO}_{2}=21 \%$ )] for 10 consecutive days, with controlled end-tidal $\mathrm{CO}_{2}$ level $(2 \mathrm{mmHg}$ above resting values) (89). A subset of four participants received additional sham exposure (room air). After each single IH session, an increase in minute ventilation $30 \mathrm{~min}$ after $\mathrm{IH}$ exposure was observed, whereas no change was observed following sham exposure to room air. These results occurred within the first 2 days of IH exposure, and persisted throughout the 10 days of exposure to IH. The magnitude of ventilatory LTF remained enhanced 10 days after the intervention in some $(n=2)$ but not all participants.

The effect of hypoxic conditioning in the field of cognitive performances has also been explored in healthy older individuals. In a recent randomized controlled trial, 34 retired healthy subjects (60-70 years), not physically active and cognitively preserved (MMSE $>27 / 30$ ), were assigned either to a normoxic group (control group, $n=17$, targeted $\mathrm{SpO}_{2}=94-98 \%$ ) or to a hypoxic group ( $n=17$, alternating $10 \mathrm{~min}$ hypoxia and $5 \mathrm{~min}$ of normoxia, $\mathrm{FiO}_{2}$ in hypoxia was adjusted to reach a $\mathrm{SpO}_{2}=90 \%$ the first 2 weeks, $85 \%$ the third week, and $80 \%$ in the last 3 weeks during hypoxia). Both groups were subjected to 1-h sessions (normoxia/hypoxia), three times a week for 6 weeks. Thirty minutes strength-endurance training followed each normoxic/hypoxic session. Combining IH exposure and exercise training enhanced cognitive performance and quality of life to a greater extent than exercise training alone (87).

On the basis of these clinical findings and according for instance to promising results in animal models of Alzheimer's disease submitted to IH (121), further research is needed to evaluate the effect of $\mathrm{IH}$ exposure in neurological conditions and the potential of hypoxic conditioning as a preventive or therapeutic tool for these diseases. As physical activity, by triggering beneficial neurovascular adaptations (122), hypoxic conditioning may be a promising therapeutic strategy to prevent or slow down brain aging.

\section{Respiratory Diseases}

Although exposing patients with respiratory illnesses to IH may seem provocative, some data suggest that hypoxic conditioning may also be considered for these patients.

\section{Obstructive Sleep Apnea Syndrome}

Considering OSAS patients, a decrease in upper airway resistance following moderate IH protocol [11 subjects with severe OSAS, exposed during non-rapid eye movement to 10 cycles of 3-min hypoxia $\left(\mathrm{FiO}_{2}=8 \%\right)$ followed by $5 \mathrm{~min}$ of room air] has been shown, indicating a LTF of upper airway dilatators (90). The same IH paradigm does not alter upper airway critical closing pressure within the same population (91). This may support the use of $\mathrm{IH}$ as an adjunct therapy in OSAS, in combination with other conventional treatments (e.g., continuous positive airway pressure), as suggested by Mateika et al. in their recent review (123). Additional work is, however, required to optimize IH protocols before translating it to therapeutic interventions.

\section{Chronic Obstructive Pulmonary Disease}

The effects of repetitive bouts of mild acute $\mathrm{IH}$ [15 sessions over 3 weeks, three to five hypoxic bouts $\left(\mathrm{FiO}_{2}=12-15 \%\right)$, each lasting 3-5 min, separated by 3 min normoxic intervals], were evaluated in 18 eucapnic normoxic mild chronic obstructive pulmonary disease (COPD) patients according to a randomized controlled 
and double blind study design. Increased total hemoglobin mass, exercise time to anaerobic threshold, and total exercise time were demonstrated (92) as well as improved baroreflex sensitivity up to normal levels and enhanced hypercapnic ventilatory response without changes in hypoxic ventilatory response (93).

\section{Metabolic Diseases}

The use of $\mathrm{IH}$ to induce weight loss has been suggested since hypoxia can increase energy expenditure $(98,124)$. Obese subjects submitted to hypobaric hypoxia (1 week at $2650 \mathrm{~m}$ ) showed weight loss, increased basal metabolic rate, and decreased food intake (125). Combining hypoxic exposure with physical activity has been reported to potentiate weight loss. Netzer et al. (94) randomly exposed 20 obese individuals (mean body mass index $=33.1 \mathrm{~kg} / \mathrm{m}^{2}$ ) to an 8 -week training program (three $90 \mathrm{~min}$ sessions per week) at $60 \%$ of their individual maximal oxygen uptake either in normobaric hypoxia $\left(\mathrm{FiO}_{2}=15 \%\right)$ or in normoxia (sham, $\mathrm{FiO}_{2}=20.1 \%$ ), without any dietary intervention. Subjects in the hypoxic group lost significantly more weight (1.14 versus $0.03 \mathrm{Kg}$ ) than the sham group. Wiesner et al. (95) submitted sedentary, non-diabetic or insulin-resistant, overweight or obese subjects to a treadmill-training, $60 \mathrm{~min}$ a day, thrice weekly over a 4 -week period at a heart rate corresponding to $65 \%$ of their maximum oxygen uptake under normoxia (normoxic group, $n=21, \mathrm{FiO}_{2}=21 \%$ ) or normobaric hypoxia (hypoxic group, $\left.n=24, \mathrm{FiO}_{2}=15 \%\right)$. Both groups showed similar improvement in maximal oxygen uptake, despite a smaller training workload in the hypoxic group. Body composition improved more (i.e., greater reduction in body-fat mass) in the hypoxic group. More recently, Kong et al. (99) randomly assigned 22 young obese subjects (17-25 years, body mass index $\left.>27.5 \mathrm{~kg} / \mathrm{m}^{2}\right)$ to either a normobaric hypoxic $\left(\mathrm{FiO}_{2}=16.4-14.5 \%\right.$, three $2 \mathrm{~h}$ sessions per week, cumulative exposure of $6 \mathrm{~h} /$ week $)$ or a normoxic $\left(\mathrm{FiO}_{2}=21 \%\right)$ training for 4 weeks. Combined with a low-calorie intake diet and a strength-endurance training program, both groups exhibited weight loss, but weight loss was significantly greater in the hypoxic group. In addition, hypoxic exposure improved systolic blood pressure and mean blood pressure. Taken together, these arguments are supportive of $\mathrm{IH}$ as an adjunct therapy to enhance weight loss in obese patients. In a recent review, Urdampilleta et al. (126) proposed an IH conditioning protocol targeting both weight loss and aerobic capacity improvement. This protocol would consist in IH exposure three times per week, during 3-6 weeks, with a target $\mathrm{FiO}_{2}$ of $10-12 \%$, with or without physical training (20-30 min strength-resistance exercises and $30 \mathrm{~min}$ highintensity aerobic exercise).

Based on preclinical data (127), hypoxic conditioning has been tested in type 2 diabetes. Eight type 2 diabetic patients completed four 60-min sessions (interspersed by 7-14 days) of normoxic rest, normoxic exercise, hypoxic rest, and hypoxic exercise $\left(\mathrm{FiO}_{2}=14.6 \pm 0.4 \%\right)(41)$. Exercise intensity was set at $90 \%$ of lactate threshold. Acute hypoxic exposure both at rest and during exercise increased insulin sensitivity (96). In another study from the same group, eight type 2 diabetic males first performed $60 \mathrm{~min}$ of hypoxic exercise $\left(\mathrm{FiO}_{2}=14.7 \pm 0.2 \%\right.$, exercise intensity at $90 \%$ of lactate threshold $=49 \pm 4$ Watts) and then 40 - and 20-min exercise sessions at a higher intensity (at $70 \pm 9$ and $140 \pm 12$
Watts, respectively) to provide similar total workload. This protocol induced an acute- $(24 \mathrm{~h})$ and moderate-term $(48 \mathrm{~h})$ improvement in insulin sensitivity following the 40- and 60-min hypoxic exercise sessions. This emphasizes the role of exercise duration or intensity (rather than the total workload completed) on glucose control in type 2 diabetics (97). Although encouraging, the beneficial effects of hypoxic conditioning for diabetic patients have nonetheless to be further evaluated by additional clinical studies.

\section{Remaining Questions and Perspectives for Future Researches}

Although the bench-based foundation for ischemic and hypoxic conditioning is strong, the translation of conditioning strategies into effective, validated therapies and clinical practice is so far mostly missing. The above results reported in patients, despite frequent important weakness in study design, suggest several promising applications for hypoxic conditioning as a nonpharmacological intervention for prevention or recovery in many pathological conditions. To successfully address the challenge of translating the strong experimental and preclinical data regarding conditioning strategies into potential clinical applications, several important issues have to be considered. Many questions remain regarding the optimal conditioning stimulus, the most favorable clinical setting to apply the conditioning phenomenon, and whether a conditioning response can always be induced in humans who, in contrast to laboratory animals, are elderly and have multiple comorbidities. Since hypoxic conditioning is part of a continuum from normoxia to deleterious severe hypoxia (Figure 2), suitable biomarkers to identify in humans the occurrence of hypoxic conditioning are needed.

Various conditioning stimuli such as exposure to ischemia, hypoxia, metabolic inhibition, or inflammation below the threshold of damage have been tested mostly in animal models and in some cases in humans. Several conditioning strategies involved drug administration and were potentially associated with important limitations in terms of clinical application due to tolerance issues, potential adverse effects, and clinical approval. Conversely, non-pharmacological ischemic or hypoxic conditioning strategies provide reasonable safety/toxicity profiles and appear to be well tolerated in patients. Among the non-pharmacological conditioning strategies, RIC (e.g., limb ischemia to induce organ protection) has been mostly tested in recent large clinical studies. Although hypoxic conditioning and RIC may induce some common mechanisms, these two attractive and relatively easy to implement conditioning strategies have to be compared in order to determine which one should be the most efficient and practical for the clinic.

Although preclinical studies demonstrated the striking ability of preconditioning strategies to protect against ischemic injuries, in most clinical settings demonstration of the therapeutic potential of preconditioning against major insults may not be readily achievable. Stroke as well as cardiac arrest is mostly of unpredictable nature, which makes clinical validation of anticipatory treatment with preconditioning strategy difficult. In addition, most preconditioning models induce short-term protection (i.e., $<72 \mathrm{~h}$ ), while more prolonged state of protection or regeneration are needed for many clinical settings. Hence, clinical validation 


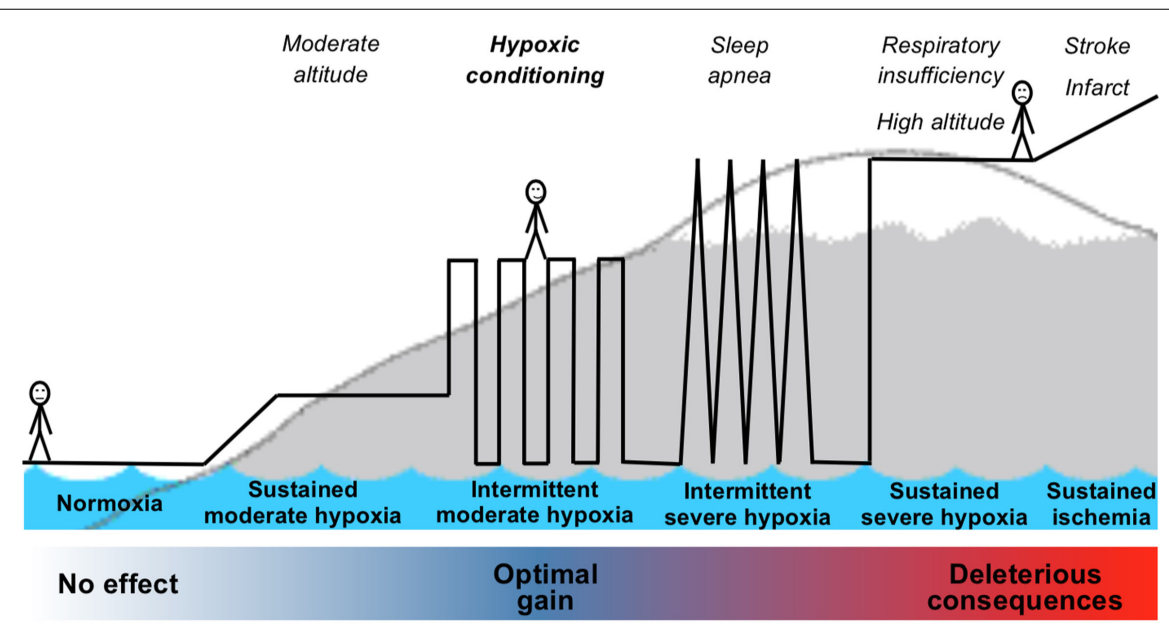

FIGURE 2 | Schematic representation of the continuum from normoxia to severe hypoxia including hypoxic exposure leading to hypoxic conditioning

and application of new conditioning strategies inducing sustained state of protection and regeneration such as prolonged hypoxic conditioning may be most appropriate (i) to improve risk factors for cardiovascular, metabolic, and neurological diseases in populations not yet presenting acute insults or advanced degenerative diseases (e.g., older individuals), (ii) as an intervention aiming to antagonize and even reverse degenerative processes associated with chronic disorders (e.g., neurological disorders), and (iii) as a regenerative treatment following acute ischemic insult (e.g., following infarct).

The dose response of a conditioning stimuli is thought to range from no response at low intensities to a protected state at higher intensities while a further increase in stimulus intensity would cause tissue damage. The therapeutic range of conditioning may be therefore relatively narrow. Although grouped within the term hypoxic conditioning, the interventions used in the human studies described above vary greatly in terms of hypoxic exposure duration, frequency, and severity (Table 1). Since all stimuli are defined by their frequency, magnitude, and duration, optimal titration of the repetitive stimulus is critical in order to provide proofs of concept and practical guidelines for hypoxic conditioning.

Responses to conditioning stimuli might be specific to sex, dependent on age, and affected by medical comorbidities. Large inter-individual differences exist in the response to identical hypoxic stimulus due to variations in oxygen regulated gene expression. This was shown for VEGF and other downstream genes of HIF-1, suggesting that the source of this variation resides within the HIF system itself (128). There are also epigenetic

\section{References}

1. Lavie L. Obstructive sleep apnoea syndrome - an oxidative stress disorder. Sleep Med Rev (2003) 7(1):35-51. doi:10.1053/smrv.2002.0261

2. Baguet JP, Barone-Rochette G, Tamisier R, Levy P, Pepin JL. Mechanisms of cardiac dysfunction in obstructive sleep apnea. Nat Rev Cardiol (2012) 9(12):679-88. doi:10.1038/nrcardio.2012.141

3. Schulz R, Mahmoudi S, Hattar K, Sibelius U, Olschewski H, Mayer K, et al. Enhanced release of superoxide from polymorphonuclear neutrophils differences between individuals as well as environmental and life style related variables that may affect the hypoxic conditioning mechanisms. Titration to define the optimal individual dose of hypoxia for subsequent hypoxic conditioning program may be needed to obtain the largest benefits without adverse effects.

Appropriate titration of the conditioning stimulus will depend on reliable and validated biomarkers that remain to be determined. It is therefore critical to identify suitable biomarkers and most probably arrays of biomarkers to detect whether a conditioning response is actually occurring or conversely whether some deleterious consequences of $\mathrm{IH}$ are induced as well as to distinguish responders and non-responders to a given conditioning strategy. Further animal studies are needed to determine such biomarkers specific to hypoxic conditioning, which should subsequently be validated in humans.

There is an increasing number of commercially available devices permitting hypoxic exposure. These devices use technologies to reduce inhaled oxygen concentrations from the normal $21 \%$ to below $10 \%$. Exposure can be done by hypoxic breathing through a mask or inside a confined space like tents or rooms while resting, sleeping, or exercising. These products are however mostly designed for athletes and healthy individuals. The use of hypoxic conditioning as a therapeutic strategy in patients would require the use of specific technologies permitting controlled, safe, and inexpensive IH exposure. Although the technologies mostly exist, their integration within validated and certified medical devices represents an important challenge for a large-scale use of hypoxic conditioning as a preventive and treatment strategy in various clinical settings.

in obstructive sleep apnea. Impact of continuous positive airway pressure therapy. Am J Respir Crit Care Med (2000) 162(2 Pt 1):566-70. doi:10.1164/ ajrccm.162.2.9908091

4. Garvey JF, Taylor CT, McNicholas WT. Cardiovascular disease in obstructive sleep apnoea syndrome: the role of intermittent hypoxia and inflammation. Eur Respir J (2009) 33(5):1195-205. doi:10.1183/09031936.00111208

5. Lévy P, Tamisier R, Minville C, Launois S, Pépin JL. Sleep apnoea syndrome in 2011: current concepts and future directions. Eur Respir Rev (2011) 20(121):134-46. doi:10.1183/09059180.00003111 
6. Tamisier R, Gilmartin GS, Launois SH, Pepin JL, Nespoulet H, Thomas R, et al. A new model of chronic intermittent hypoxia in humans: effect on ventilation, sleep, and blood pressure. J Appl Physiol (2009) 107(1):17-24. doi:10.1152/japplphysiol.91165.2008

7. Tamisier R, Pepin JL, Remy J, Baguet JP, Taylor JA, Weiss JW, et al. 14 nights of intermittent hypoxia elevate daytime blood pressure and sympathetic activity in healthy humans. Eur Respir J (2011) 37(1):119-28. doi:10.1183/09031936. 00204209

8. Millet GP, Roels B, Schmitt L, Woorons X, Richalet JP. Combining hypoxic methods for peak performance. Sports Med (2010) 40(1):1-25. doi:10.2165/ 11317920-000000000-00000

9. Santos JL, Perez-Bravo F, Carrasco E, Calvillan M, Albala C. Low prevalence of type 2 diabetes despite a high average body mass index in the Aymara natives from Chile. Nutrition (2001) 17(4):305-9. doi:10.1016/S0899-9007(00) 00551-7

10. Sherpa LY, Deji, Stigum H, Chongsuvivatwong V, Thelle DS, Bjertness E. Obesity in Tibetans aged 30-70 living at different altitudes under the north and south faces of Mt. Everest. Int J Environ Res Public Health (2010) 7(4):1670-80. doi:10.3390/ijerph7041670

11. Voss JD, Masuoka P, Webber BJ, Scher AI, Atkinson RL. Association of elevation, urbanization and ambient temperature with obesity prevalence in the United States. Int J Obes (2013) 37(10):1407-12. doi:10.1038/ ijo. 2013.5

12. Lavie L, Lavie P. Ischemic preconditioning as a possible explanation for the age decline relative mortality in sleep apnea. Med Hypotheses (2006) 66(6):1069-73. doi:10.1016/j.mehy.2005.10.033

13. Steiner S, Schueller PO, Schulze V, Strauer BE. Occurrence of coronary collateral vessels in patients with sleep apnea and total coronary occlusion. Chest (2010) 137(3):516-20. doi:10.1378/chest.09-1136

14. Lavie L. Oxidative stress in obstructive sleep apnea and intermittent hypoxiarevisited - the bad ugly and good: implications to the heart and brain. Sleep Med Rev (2014) 20:27-45. doi:10.1016/j.smrv.2014.07.003

15. Moncayo J, de Freitas GR, Bogousslavsky J, Altieri M, van Melle G. Do transient ischemic attacks have a neuroprotective effect? Neurology (2000) 54(11):2089-94. doi:10.1212/WNL.54.11.2089

16. Weih M, Kallenberg K, Bergk A, Dirnagl U, Harms L, Wernecke KD, et al. Attenuated stroke severity after prodromal TIA: a role for ischemic tolerance in the brain? Stroke (1999) 30(9):1851-4. doi:10.1161/01.STR.30.9. 1851

17. Murry CE, Jennings RB, Reimer KA. Preconditioning with ischemia: a delay of lethal cell injury in ischemic myocardium. Circulation (1986) 74(5):1124-36. doi:10.1161/01.CIR.74.5.1124

18. Shizukuda Y, Mallet RT, Lee SC, Downey HF. Hypoxic preconditioning of ischaemic canine myocardium. Cardiovasc Res (1992) 26(5):534-42. doi:10. $1093 / \mathrm{cvr} / 26.5 .534$

19. Beguin PC, Belaidi E, Godin-Ribuot D, Levy P, Ribuot C. Intermittent hypoxia-induced delayed cardioprotection is mediated by $\mathrm{PKC}$ and triggered by p38 MAP kinase and Erk1/2. J Mol Cell Cardiol (2007) 42(2):343-51. doi:10.1016/j.yjmcc.2006.11.008

20. Beguin PC, Joyeux-Faure M, Godin-Ribuot D, Levy P, Ribuot C. Acute intermittent hypoxia improves rat myocardium tolerance to ischemia. J Appl Physiol (2005) 99(3):1064-9. doi:10.1152/japplphysiol.00056.2005

21. Belaidi E, Beguin PC, Levy P, Ribuot C, Godin-Ribuot D. Prevention of HIF1 activation and iNOS gene targeting by low-dose cadmium results in loss of myocardial hypoxic preconditioning in the rat. Am J Physiol Heart Circ Physiol (2008) 294(2):H901-8. doi:10.1152/ajpheart.00715.2007

22. Dahl NA, Balfour WM. Prolonged anoxic survival due to anoxia pre-exposure: brain ATP, lactate, and pyruvate. Am J Physiol (1964) 207:452-6.

23. Schurr A, Reid KH, Tseng MT, West C, Rigor BM. Adaptation of adult brain tissue to anoxia and hypoxia in vitro. Brain Res (1986) 374(2):244-8. doi:10. 1016/0006-8993(86)90418-X

24. Kitagawa K, Matsumoto M, Tagaya M, Hata R, Ueda H, Niinobe $M$, et al. "Ischemic tolerance" phenomenon found in the brain. Brain Res (1990) 528(1):21-4. doi:10.1016/0006-8993(90)90189-I

25. Hurtado A. Some clinical aspects of life at high altitudes. Ann Intern Med (1960) 53:247-58. doi:10.7326/0003-4819-53-2-247

26. Meerson FZ, Gomzakov OA, Shimkovich MV. Adaptation to high altitude hypoxia as a factor preventing development of myocardial ischemic necrosis. Am J Cardiol (1973) 31(1):30-4. doi:10.1016/0002-9149(73)90806-0
27. Neckar J, Papousek F, Novakova O, Ost’adal B, Kolar F. Cardioprotective effects of chronic hypoxia and ischaemic preconditioning are not additive. Basic Res Cardiol (2002) 97(2):161-7. doi:10.1007/s003950200007

28. Meerson FZ, Malyshev I. Adaptation to stress increases the heart resistance to ischemic and reperfusion arrhythmias. J Mol Cell Cardiol (1989) 21(3):299-303. doi:10.1016/0022-2828(89)90745-1

29. Meerson FZ, Ustinova EE, Orlova EH. Prevention and elimination of heart arrhythmias by adaptation to intermittent high altitude hypoxia. Clin Cardiol (1987) 10(12):783-9. doi:10.1002/clc.4960101202

30. Asemu G, Neckar J, Szarszoi O, Papousek F, Ostadal B, Kolar F. Effects of adaptation to intermittent high altitude hypoxia on ischemic ventricular arrhythmias in rats. Physiol Res (2000) 49(5):597-606.

31. Dong JW, Zhu HF, Zhu WZ, Ding HL, Ma TM, Zhou ZN. Intermittent hypoxia attenuates ischemia/reperfusion induced apoptosis in cardiac myocytes via regulating Bcl-2/Bax expression. Cell Res (2003) 13(5):385-91. doi:10.1038/sj. cr.7290184

32. Zhuang J, Zhou Z. Protective effects of intermittent hypoxic adaptation on myocardium and its mechanisms. Biol Signals Recept (1999) 8(4-5):316-22. doi:10.1159/000014602

33. Kolar F, Ostadal B. Molecular mechanisms of cardiac protection by adaptation to chronic hypoxia. Physiol Res (2004) 53(Suppl 1):S3-13.

34. Neckar J, Ostadal B, Kolar F. Myocardial infarct size-limiting effect of chronic hypoxia persists for five weeks of normoxic recovery. Physiol Res (2004) 53(6):621-8.

35. Stowe AM, Altay T, Freie AB, Gidday JM. Repetitive hypoxia extends endogenous neurovascular protection for stroke. Ann Neurol (2011) 69(6):975-85. doi:10.1002/ana.22367

36. Zhu Y, Zhang Y, Ojwang BA, Brantley MA Jr, Gidday JM. Long-term tolerance to retinal ischemia by repetitive hypoxic preconditioning: role of HIF1alpha and heme oxygenase-1. Invest Ophthalmol Vis Sci (2007) 48(4):1735-43. doi:10.1167/iovs.06-1037

37. Zhao ZQ, Corvera JS, Halkos ME, Kerendi F, Wang NP, Guyton RA, et al. Inhibition of myocardial injury by ischemic postconditioning during reperfusion: comparison with ischemic preconditioning. Am J Physiol Heart Circ Physiol (2003) 285(2):H579-88. doi:10.1152/ajpheart.01064.2002

38. Tsai YW, Yang YR, Wang PS, Wang RY. Intermittent hypoxia after transient focal ischemia induces hippocampal neurogenesis and c-Fos expression and reverses spatial memory deficits in rats. PLoS One (2011) 6(8):e24001. doi:10. 1371/journal.pone.0024001

39. Arkhipenko YV, Sazontova TG, Zhukova AG. Adaptation to periodic hypoxia and hyperoxia improves resistance of membrane structures in heart, liver, and brain. Bull Exp Biol Med (2005) 140(3):278-81. doi:10.1007/ s10517-005-0466-0

40. Gonchar O, Mankovska I. Moderate hypoxia/hyperoxia attenuates acute hypoxia-induced oxidative damage and improves antioxidant defense in lung mitochondria. Acta Physiol Hung (2012) 99(4):436-46. doi:10.1556/APhysiol. 99.2012.4.8

41. Semenza GL. Regulation of oxygen homeostasis by hypoxia-inducible factor 1. Physiology (2009) 24:97-106. doi:10.1152/physiol.00045.2008

42. Cai Z, Zhong H, Bosch-Marce M, Fox-Talbot K, Wang L, Wei C, et al. Complete loss of ischaemic preconditioning-induced cardioprotection in mice with partial deficiency of HIF-1 alpha. Cardiovasc Res (2008) 77(3):463-70. doi:10.1093/cvr/cvm035

43. Huang T, Huang W, Zhang Z, Yu L, Xie C, Zhu D, et al. Hypoxia-inducible factor-1alpha upregulation in microglia following hypoxia protects against ischemia-induced cerebral infarction. Neuroreport (2014) 25(14):1122-8. doi:10.1097/WNR.0000000000000236

44. Murillo D, Kamga C, Mo L, Shiva S. Nitrite as a mediator of ischemic preconditioning and cytoprotection. Nitric Oxide (2011) 25(2):70-80. doi:10.1016/j. niox.2011.01.003

45. Gess B, Schricker K, Pfeifer M, Kurtz A. Acute hypoxia upregulates NOS gene expression in rats. Am J Physiol (1997) 273(3 t 2):R905-10.

46. Xi L, Tekin D, Gursoy E, Salloum F, Levasseur JE, Kukreja RC. Evidence that NOS2 acts as a trigger and mediator of late preconditioning induced by acute systemic hypoxia. Am J Physiol Heart Circ Physiol (2002) 283(1):H5-12. doi:10.1152/ajpheart.00920.2001

47. Park AM, Nagase H, Vinod Kumar S, Suzuki YJ. Acute intermittent hypoxia activates myocardial cell survival signaling. Am J Physiol Heart Circ Physiol (2007) 292(2):H751-7. doi:10.1152/ajpheart.01016.2006 
48. Ding HL, Zhu HF, Dong JW, Zhu WZ, Yang WW, Yang HT, et al. Inducible nitric oxide synthase contributes to intermittent hypoxia against ischemia/reperfusion injury. Acta Pharmacol Sin (2005) 26(3):315-22. doi:10. 1111/j.1745-7254.2005.00046.x

49. Zhu HF, Dong JW, Zhu WZ, Ding HL, Zhou ZN. ATP-dependent potassium channels involved in the cardiac protection induced by intermittent hypoxia against ischemia/reperfusion injury. Life Sci (2003) 73(10):1275-87. doi:10. 1016/S0024-3205(03)00429-6

50. Moore-Gillon JC, Cameron IR. Right ventricular hypertrophy and polycythaemia in rats after intermittent exposure to hypoxia. Clin Sci (Lond) (1985) 69(5):595-9.

51. Joyeux-Faure M, Godin-Ribuot D, Ribuot C. Erythropoietin and myocardial protection: what's new? Fundam Clin Pharmacol (2005) 19(4):439-46. doi:10. $1111 / j .1472-8206.2005 .00347 . x$

52. Moore E, Bellomo R. Erythropoietin (EPO) in acute kidney injury. Ann Intensive Care (2011) 1(1):3. doi:10.1186/2110-5820-1-3

53. Ruscher K, Freyer D, Karsch M, Isaev N, Megow D, Sawitzki B, et al. Erythropoietin is a paracrine mediator of ischemic tolerance in the brain: evidence from an in vitro model. J Neurosci (2002) 22(23):10291-301.

54. Wu L, Tan JL, Wang ZH, Chen YX, Gao L, Liu JL, et al. ROS generated during early reperfusion contribute to intermittent hypobaric hypoxia-afforded cardioprotection against postischemia-induced Ca overload and contractile dysfunction via the JAK2/STAT3 pathway. J Mol Cell Cardiol (2015) 81:150-61. doi:10.1016/j.yjmcc.2015.02.015

55. Ravingerova T, Matejikova J, Neckar J, Andelova E, Kolar F. Differential role of PI3K/Akt pathway in the infarct size limitation and antiarrhythmic protection in the rat heart. Mol Cell Biochem (2007) 297(1-2):111-20. doi:10. 1007/s11010-006-9335-z

56. Milano G, Abruzzo PM, Bolotta A, Marini M, Terraneo L, Ravara B, et al. Impact of the phosphatidylinositide 3-kinase signaling pathway on the cardioprotection induced by intermittent hypoxia. PLoS One (2013) 8(10):e76659. doi:10.1371/journal.pone.0076659

57. Leconte C, Tixier E, Freret T, Toutain J, Saulnier R, Boulouard M, et al. Delayed hypoxic postconditioning protects against cerebral ischemia in the mouse. Stroke (2009) 40(10):3349-55. doi:10.1161/STROKEAHA.109.557314

58. Zhong N, Zhang Y, Zhu HF, Wang JC, Fang QZ, Zhou ZN. Myocardial capillary angiogenesis and coronary flow in ischemia tolerance rat by adaptation to intermittent high altitude hypoxia. Acta Pharmacol Sin (2002) 23(4):305-10.

59. Ramond A, Samuel JL, Tonini J, Sanchez H, Ribuot C, Lévy P, et al. Effect of chronic intermittent hypoxia on cardiac angiogenesis and mitochondrial function. Fundam Clin Pharmacol (2008) 22:52.

60. Yeh CH, Hsu SP, Yang CC, Chien CT, Wang NP. Hypoxic preconditioning reinforces HIF-alpha-dependent HSP70 signaling to reduce ischemic renal failure-induced renal tubular apoptosis and autophagy. Life Sci (2010) 86(3-4):115-23. doi:10.1016/j.lfs.2009.11.022

61. Joyeux-Faure M, Arnaud C, Godin-Ribuot D, Ribuot C. Heat stress preconditioning and delayed myocardial protection: what is new? Cardiovasc Res (2003) 60(3):469-77. doi:10.1016/j.cardiores.2003.08.012

62. Zhong N, Zhang Y, Fang QZ, Zhou ZN. Intermittent hypoxia exposureinduced heat-shock protein 70 expression increases resistance of rat heart to ischemic injury. Acta Pharmacol Sin (2000) 21(5):467-72.

63. Lundby C, Millet GP, Calbet JA, Bartsch P, Subudhi AW. Does "altitude training" increase exercise performance in elite athletes? Br JSports Med (2012) 46(11):792-5. doi:10.1136/bjsports-2012-091231

64. Wilber RL. Application of altitude/hypoxic training by elite athletes. Med Sci Sports Exerc (2007) 39(9):1610-24. doi:10.1249/mss.0b013e3180de49e6

65. Richalet JP, Souberbielle JC, Antezana AM, Dechaux M, Le Trong JL, Bienvenu A, et al. Control of erythropoiesis in humans during prolonged exposure to the altitude of 6,542 m. Am J Physiol (1994) 266(3 Pt 2):R756-64

66. Rodriguez FA, Casas H, Casas M, Pages T, Rama R, Ricart A, et al. Intermittent hypobaric hypoxia stimulates erythropoiesis and improves aerobic capacity. Med Sci Sports Exerc (1999) 31(2):264-8. doi:10.1097/ 00005768-199902000-00010

67. Hellemans J, editor. Intermittent hypoxic training: a pilot study. Proceedings of the 2nd Annual International Altitude Training Symposium. Flagstaff, AZ: High Altitude Sports Training Complex, Northern Arizona University (1999).

68. Garcia N, Hopkins SR, Powell FL. Intermittent vs continuous hypoxia: effects on ventilation and erythropoiesis in humans. Wilderness Environ Med (2000) 11(3):172-9. doi:10.1580/1080-6032(2000)011[0172:IVCHEO]2.3.CO;2
69. Mitchell GS, Johnson SM. Neuroplasticity in respiratory motor control. J Appl Physiol (2003) 94(1):358-74. doi:10.1152/japplphysiol.00523.2002

70. Mateika JH, Syed Z. Intermittent hypoxia, respiratory plasticity and sleep apnea in humans: present knowledge and future investigations. Respir Physiol Neurobiol (2013) 188(3):289-300. doi:10.1016/j.resp.2013.04.010

71. Shkoukani M, Babcock MA, Badr MS. Effect of episodic hypoxia on upper airway mechanics in humans during NREM sleep. J Appl Physiol (2002) 92(6):2565-70. doi:10.1152/japplphysiol.00938.2001

72. Babcock MA, Badr MS. Long-term facilitation of ventilation in humans during NREM sleep. Sleep (1998) 21(7):709-16.

73. Chowdhuri S, Pierchala L, Aboubakr SE, Shkoukani M, Badr MS. Long-term facilitation of genioglossus activity is present in normal humans during NREM sleep. Respir Physiol Neurobiol (2008) 160(1):65-75. doi:10.1016/j.resp.2007. 08.007

74. Shatilo VB, Korkushko OV, Ischuk VA, Downey HF, Serebrovskaya TV. Effects of intermittent hypoxia training on exercise performance, hemodynamics, and ventilation in healthy senior men. High Alt Med Biol (2008) 9(1):43-52. doi:10.1089/ham.2008.1053

75. Bailey DM, Davies B, Baker J. Training in hypoxia: modulation of metabolic and cardiovascular risk factors in men. Med Sci Sports Exerc (2000) 32(6):1058-66. doi:10.1097/00005768-200006000-00004

76. Mitchell GF, Hwang SJ, Vasan RS, Larson MG, Pencina MJ, Hamburg NM, et al. Arterial stiffness and cardiovascular events: the Framingham heart study. Circulation (2010) 121(4):505-11. doi:10.1161/CIRCULATIONAHA. 109.886655

77. Nishiwaki M, Kawakami R, Saito K, Tamaki H, Takekura H, Ogita F. Vascular adaptations to hypobaric hypoxic training in postmenopausal women. $J$ Physiol Sci (2011) 61(2):83-91. doi:10.1007/s12576-010-0126-7

78. Vedam H, Phillips CL, Wang D, Barnes DJ, Hedner JA, Unger G, et al. Shortterm hypoxia reduces arterial stiffness in healthy men. Eur J Appl Physiol (2009) 105(1):19-25. doi:10.1007/s00421-008-0868-6

79. Chiu LL, Chou SW, Cho YM, Ho HY, Ivy JL, Hunt D, et al. Effect of prolonged intermittent hypoxia and exercise training on glucose tolerance and muscle GLUT4 protein expression in rats. J Biomed Sci (2004) 11(6):838-46. doi:10. 1007/BF02254369

80. Ling Q, Sailan W, Ran J, Zhi S, Cen L, Yang X, et al. The effect of intermittent hypoxia on bodyweight, serum glucose and cholesterol in obesity mice. Pak J Biol Sci (2008) 11(6):869-75. doi:10.3923/pjbs.2008.869.875

81. Takahashi H, Asano K, Nakayama H. Effect of endurance training under hypoxic condition on oxidative enzyme activity in rat skeletal muscle. Appl Hum Sci (1996) 15(3):111-4. doi:10.2114/jpa.15.111

82. Haufe S, Wiesner S, Engeli S, Luft FC, Jordan J. Influences of normobaric hypoxia training on metabolic risk markers in human subjects. Med Sci Sports Exerc (2008) 40(11):1939-44. doi:10.1249/MSS.0b013e31817f1988

83. Bailey DP, Smith LR, Chrismas BC, Taylor L, Stensel DJ, Deighton K, et al. Appetite and gut hormone responses to moderate-intensity continuous exercise versus high-intensity interval exercise, in normoxic and hypoxic conditions. Appetite (2015) 89:237-45. doi:10.1016/j.appet.2015.02.019

84. Burtscher M, Pachinger O, Ehrenbourg I, Mitterbauer G, Faulhaber M, Puhringer $\mathrm{R}$, et al. Intermittent hypoxia increases exercise tolerance in elderly men with and without coronary artery disease. Int J Cardiol (2004) 96(2):247-54. doi:10.1016/j.ijcard.2003.07.021

85. Lyamina NP, Lyamina SV, Senchiknin VN, Mallet RT, Downey HF, Manukhina EB. Normobaric hypoxia conditioning reduces blood pressure and normalizes nitric oxide synthesis in patients with arterial hypertension. J Hypertens (2011) 29(11):2265-72. doi:10.1097/HJH.0b013e32834b5846

86. Trumbower RD, Jayaraman A, Mitchell GS, Rymer WZ. Exposure to acute intermittent hypoxia augments somatic motor function in humans with incomplete spinal cord injury. Neurorehabil Neural Repair (2012) 26(2):163-72. doi:10.1177/1545968311412055

87. Schega L, Peter B, Torpel A, Mutschler H, Isermann B, Hamacher D. Effects of intermittent hypoxia on cognitive performance and quality of life in elderly adults: a pilot study. Gerontology (2013) 59(4):316-23.

88. Hayes HB, Jayaraman A, Herrmann M, Mitchell GS, Rymer WZ, Trumbower RD. Daily intermittent hypoxia enhances walking after chronic spinal cord injury: a randomized trial. Neurology (2014) 82(2):104-13. doi:10.1212/01. WNL.0000437416.34298.43

89. Tester NJ, Fuller DD, Fromm JS, Spiess MR, Behrman AL, Mateika JH. Longterm facilitation of ventilation in humans with chronic spinal cord injury. 
Am J Respir Crit Care Med (2014) 189(1):57-65. doi:10.1164/rccm. 201305-0848OC

90. Aboubakr SE, Taylor A, Ford R, Siddiqi S, Badr MS. Long-term facilitation in obstructive sleep apnea patients during NREM sleep. J Appl Physiol (2001) 91(6):2751-7.

91. Rowley JA, Deebajah I, Parikh S, Najar A, Saha R, Badr MS. The influence of episodic hypoxia on upper airway collapsibility in subjects with obstructive sleep apnea. J Appl Physiol (2007) 103(3):911-6. doi:10.1152/japplphysiol. 01117.2006

92. Burtscher M, Haider T, Domej W, Linser T, Gatterer H, Faulhaber M, et al. Intermittent hypoxia increases exercise tolerance in patients at risk for or with mild COPD. Respir Physiol Neurobiol (2009) 165(1):97-103. doi:10.1016/j. resp.2008.10.012

93. Haider T, Casucci G, Linser T, Faulhaber M, Gatterer H, Ott G, et al. Interval hypoxic training improves autonomic cardiovascular and respiratory control in patients with mild chronic obstructive pulmonary disease. $J$ Hypertens (2009) 27(8):1648-54. doi:10.1097/HJH.0b013e32832c0018

94. Netzer NC, Chytra R, Kupper T. Low intense physical exercise in normobaric hypoxia leads to more weight loss in obese people than low intense physical exercise in normobaric sham hypoxia. Sleep Breath (2008) 12(2):129-34. doi:10.1007/s11325-007-0149-3

95. Wiesner S, Haufe S, Engeli S, Mutschler H, Haas U, Luft FC, et al. Influences of normobaric hypoxia training on physical fitness and metabolic risk markers in overweight to obese subjects. Obesity (2010) 18(1):116-20. doi:10.1038/oby. 2009.193

96. Mackenzie R, Maxwell N, Castle P, Brickley G, Watt P. Acute hypoxia and exercise improve insulin sensitivity $\left(\mathrm{S}(\mathrm{I})\left(2^{*}\right)\right.$ ) in individuals with type 2 diabetes. Diabetes (2011) 27(1):94-101. doi:10.1002/dmrr.1156

97. Mackenzie R, Elliott B, Maxwell N, Brickley G, Watt P. The effect of hypoxia and work intensity on insulin resistance in type 2 diabetes. J Clin Endocrinol Metab (2012) 97(1):155-62. doi:10.1210/jc.2011- 1843

98. Workman C, Basset FA. Post-metabolic response to passive normobaric hypoxic exposure in sedendary overweight males: a pilot study. Nutr Metab (2012) 9(1):103. doi:10.1186/1743-7075-9-103

99. Kong Z, Zang Y, Hu Y. Normobaric hypoxia training causes more weight loss than normoxia training after a 4 -week residential camp for obese young adults. Sleep Breath (2014) 18(3):591-7. doi:10.1007/s11325-013-0922-4

100. Manukhina EB, Downey HF, Mallet RT. Role of nitric oxide in cardiovascular adaptation to intermittent hypoxia. Exp Biol Med (2006) 231(4):343-65.

101. Manukhina EB, Jasti D, Vanin AF, Downey HF. Intermittent hypoxia conditioning prevents endothelial dysfunction and improves nitric oxide storage in spontaneously hypertensive rats. Exp Biol Med (2011) 236(7):867-73. doi:10. 1258/ebm.2011.011023

102. Serebrovskaya TV, Manukhina EB, Smith ML, Downey HF, Mallet RT. Intermittent hypoxia: cause of or therapy for systemic hypertension? Exp Biol Med (2008) 233(6):627-50. doi:10.3181/0710-MR-267

103. Manukhina EB, Belkina LM, Terekhina OL, Abramochkin DV, Smirnova EA, Budanova OP, et al. Normobaric, intermittent hypoxia conditioning is cardioand vasoprotective in rats. Exp Biol Med (2013) 238(12):1413-20. doi:10.1177/ 1535370213508718

104. Przyklenk K, Bauer B, Ovize M, Kloner RA, Whittaker P. Regional ischemic "preconditioning" protects remote virgin myocardium from subsequent sustained coronary occlusion. Circulation (1993) 87(3):893-9. doi:10.1161/01. CIR.87.3.893

105. Ndrepepa G, Mehilli J, Schwaiger M, Schuhlen H, Nekolla S, Martinoff S, et al. Prognostic value of myocardial salvage achieved by reperfusion therapy in patients with acute myocardial infarction. J Nucl Med (2004) 45(5): $725-9$.

106. Botker HE, Kharbanda R, Schmidt MR, Bottcher M, Kaltoft AK, Terkelsen CJ, et al. Remote ischaemic conditioning before hospital admission, as a complement to angioplasty, and effect on myocardial salvage in patients with acute myocardial infarction: a randomised trial. Lancet (2010) 375(9716):727-34. doi:10.1016/S0140-6736(09)62001-8

107. White SK, Frohlich GM, Sado DM, Maestrini V, Fontana M, Treibel TA, et al. Remote ischemic conditioning reduces myocardial infarct size and edema in patients with ST-segment elevation myocardial infarction. JACC Cardiovasc Interv (2015) 8(1 Pt B):178-88. doi:10.1016/j.jcin.2014.05.015
108. Naghshin J, McGaffin KR, Witham WG, Mathier MA, Romano LC, Smith $\mathrm{SH}$, et al. Chronic intermittent hypoxia increases left ventricular contractility in C57BL/6J mice. J Appl Physiol (2009) 107(3):787-93. doi:10.1152/ japplphysiol.91256.2008

109. Naghshin J, Rodriguez RH, Davis EM, Romano LC, McGaffin KR, O’Donnell CP. Chronic intermittent hypoxia exposure improves left ventricular contractility in transgenic mice with heart failure. J Appl Physiol (2012) 113(5):791-8. doi:10.1152/japplphysiol.00185.2012

110. Kono Y, Fukuda S, Hanatani A, Nakanishi K, Otsuka K, Taguchi H, et al. Remote ischemic conditioning improves coronary microcirculation in healthy subjects and patients with heart failure. Drug Des Devel Ther (2014) 8:1175-81. doi:10.2147/DDDT.S68715

111. Wegener S, Gottschalk B, Jovanovic V, Knab R, Fiebach JB, Schellinger PD, et al. Transient ischemic attacks before ischemic stroke: preconditioning the human brain? A multicenter magnetic resonance imaging study. Stroke (2004) 35(3):616-21. doi:10.1161/01.STR.0000115767.17923.6A

112. Castillo J, Moro MA, Blanco M, Leira R, Serena J, Lizasoain I, et al. The release of tumor necrosis factor-alpha is associated with ischemic tolerance in human stroke. Ann Neurol (2003) 54(6):811-9. doi:10.1002/ana.10765

113. Sitzer M, Foerch C, Neumann-Haefelin T, Steinmetz H, Misselwitz B, Kugler C, et al. Transient ischaemic attack preceding anterior circulation infarction is independently associated with favourable outcome. J Neurol Neurosurg Psychiatry (2004) 75(4):659-60. doi:10.1136/jnnp.2003.015875

114. Della Morte D, Abete P, Gallucci F, Scaglione A, D'Ambrosio D, Gargiulo G, et al. Transient ischemic attack before nonlacunar ischemic stroke in the elderly. J Stroke Cerebrovasc Dis (2008) 17(5):257-62. doi:10.1016/j. jstrokecerebrovasdis.2008.03.004

115. Hoshino T, Mizuno S, Shimizu S, Uchiyama S. Clinical features and functional outcome of stroke after transient ischemic attack. J Stroke Cerebrovasc Dis (2013) 22(3):260-6. doi:10.1016/j.jstrokecerebrovasdis.2012.05.015

116. Johnston SC. Ischemic preconditioning from transient ischemic attacks? Data from the Northern California TIA Study. Stroke (2004) 35(11 Suppl 1):2680-2. doi:10.1161/01.STR.0000143322.20491.0f

117. Tsai YW, Yang YR, Sun SH, Liang KC, Wang RY. Post ischemia intermittent hypoxia induces hippocampal neurogenesis and synaptic alterations and alleviates long-term memory impairment. J Cereb Blood Flow Metab (2013) 33(5):764-73. doi:10.1038/jcbfm.2013.15

118. Hoda MN, Siddiqui S, Herberg S, Periyasamy-Thandavan S, Bhatia K, Hafez SS, et al. Remote ischemic perconditioning is effective alone and in combination with intravenous tissue-type plasminogen activator in murine model of embolic stroke. Stroke (2012) 43(10):2794-9. doi:10.1161/STROKEAHA.112. 660373

119. Hougaard KD, Hjort N, Zeidler D, Sorensen L, Norgaard A, Hansen TM, et al. Remote ischemic perconditioning as an adjunct therapy to thrombolysis in patients with acute ischemic stroke: a randomized trial. Stroke (2014) 45(1):159-67. doi:10.1161/STROKEAHA.113.001346

120. Jaiswal PB, Tester NJ, Davenport PW. Effect of acute intermittent hypoxia treatment on ventilatory load compensation and magnitude estimation of inspiratory resistive loads in an individual with chronic incomplete cervical spinal cord injury. J Spinal Cord Med (2014). doi:10.1179/2045772314Y. 0000000277

121. Manukhina EB, Goryacheva AV, Barskov IV, Viktorov IV, Guseva AA, Pshennikova MG, et al. Prevention of neurodegenerative damage to the brain in rats in experimental Alzheimer's disease by adaptation to hypoxia. Neurosci Behav Physiol (2010) 40(7):737-43. doi:10.1007/s11055-010-9320-6

122. Tarumi T, Zhang R. Cerebral hemodynamics of the aging brain: risk of Alzheimer disease and benefit of aerobic exercise. Front Physiol (2014) 5:6. doi:10.3389/fphys.2014.00006

123. Mateika JH, El-Chami M, Shaheen D, Ivers B. Intermittent hypoxia: a low risk research tool with therapeutic value in humans. J Appl Physiol (2014) 118(5):520-32. doi:10.1152/japplphysiol.00564.2014

124. Kayser B, Verges S. Hypoxia, energy balance and obesity: from pathophysiological mechanisms to new treatment strategies. Obes Rev (2013) 14(7):579-92. doi:10.1111/obr.12034

125. Lippl FJ, Neubauer S, Schipfer S, Lichter N, Tufman A, Otto B, et al. Hypobaric hypoxia causes body weight reduction in obese subjects. Obesity (2010) 18(4):675-81. doi:10.1038/oby.2009.509 
126. Urdampilleta A, Gonzalez-Muniesa P, Portillo MP, Martinez JA. Usefulness of combining intermittent hypoxia and physical exercise in the treatment of obesity. J Physiol Biochem (2012) 68(2):289-304. doi:10.1007/s13105-011-0115-1

127. Chen CY, Tsai YL, Kao CL, Lee SD, Wu MC, Mallikarjuna K, et al. Effect of mild intermittent hypoxia on glucose tolerance, muscle morphology and AMPK-PGC-1alpha signaling. Chin J Physiol (2010) 53(1):62-71. doi:10.4077/ CJP.2010.AMK078

128. Brooks JT, Elvidge GP, Glenny L, Gleadle JM, Liu C, Ragoussis J, et al. Variations within oxygen-regulated gene expression in humans. J Appl Physiol (2009) 106(1):212-20. doi:10.1152/japplphysiol.90578.2008
Conflict of Interest Statement: The authors declare that the research was conducted in the absence of any commercial or financial relationships that could be construed as a potential conflict of interest.

Copyright $\odot 2015$ Verges, Chacaroun, Godin-Ribuot and Baillieul. This is an openaccess article distributed under the terms of the Creative Commons Attribution License (CC BY). The use, distribution or reproduction in other forums is permitted, provided the original author(s) or licensor are credited and that the original publication in this journal is cited, in accordance with accepted academic practice. No use, distribution or reproduction is permitted which does not comply with these terms. 